\title{
ESTIMATING FLOW CHARACTERISTICS OF DIFFERENT WEIR TYPES AND OPTIMUM DIMENSIONS OF DOWNSTREAM RECEIVING POOL
}

\author{
M. EMIN EMIROGLU \\ Firat University, Civil Engineering Department, Hydraulic Division, 23119, Elazig-Turkey; Mailto: memiroglu@firat.edu.tr
}

This paper presents the results of a laboratory study on the flow characteristics of sharp-crested weirs, broad-crested weirs, and labyrinth weirs. The variation of the maximum bubble penetration depth for different weir types is investigated depending on overfall jet expansion, discharge, and drop height. Moreover, most efficient depth, length and width of the downstream receiving pool in an open channel system are studied by considering the penetration depth, overfall jet expansion, jet trajectory and the bubble zone. The results show that overfall jet expansion at the labyrinth weirs is significantly wider than the rectangular sharp-crested weirs and the trapezoidal sharp-crested weir. It is demonstrated that the labyrinth weirs have the lowest values of bubble penetration depth among the weirs tested. Furthermore, it is found that the rectangular and the trapezoidal weirs are observed to have the highest bubble penetration depth among all weirs. Consequently, empirical equations are obtained for predicting the maximum penetration depth of bubbles, trajectory of free overfall nappe, jet expansion of free overfall nappe, and the length of the bubble zone.

KEY WORDS: Weir, Penetration Depth, Jet Expansion, Jet Trajectory, Bubble, Air Entrainment, Aeration.

M. Emin Emiroglu: URČOVANIE PRÚDOVÝCH CHARAKTERISTÍK ROZDIELNYCH TYPOV PRIEPADOV A OPTIMÁLNY NÁVRH VÝVARU. J. Hydrol. Hydromech., 58, 2010, 4; 28 lit., 13 obr., 4 tab.

Príspevok prezentuje výsledky laboratórneho výskumu charakteristík prúdenia cez ostrohranné priepady, cez priepady so širokou hranou a cez labyrintové priepady. Bola študovaná variácia maximálnej híbky prieniku vzduchových bublín pre rozdielne typy priepadov v závislosti od rozšírenia prúdu, prietoku a výšky priepadu. Okrem toho bola analyzovaná efektívna híbka, šírka a dížka vývaru v systéme otvorených kanálov s uvážením rozšírenia prúdu, prietoku a výšky priepadu a oblasti so vzduchovými bublinami. Z výsledkov vyplýva, že rozšírenie prúdu pri labyrintových priepadoch je výrazne väčšie, ako pri pravouhlých a lichobežníkových ostrohranných priepadoch. Bolo ukázané, že labyrintové priepady majú najmenšiu híbku prieniku vzduchových bublín spomedzi všetkých testovaných priepadov. Zistilo sa však, že pravouhlé a lichobežníkové priepady majú najväčšie híbky prieniku vzduchových bublín spomedzi všetkých testovaných priepadov. Tieto výsledky výskumu viedli $\mathrm{k}$ empirickým rovniciam, umožňujúcim výpočet maximálnej híbky prieniku vzduchových bublín, trajektórií prepadového lúča, rozšírenia prúdu a dížky prevzdušnenej oblasti.

KLÚČOVÉ SLOVÁ: priepad, híbka prieniku vzduchových bublín, rozšŕrenie prúdu, trajektória prúdu, bublina, prevzdušňovanie.

\section{Introduction}

The overflow section shape cut with a sharp upstream corner into a thin plate is the weir notch, sometimes called the overflow section. If the notch plate is mounted on the supporting bulkhead such that the water does not contact or cling to the downstream weir plate or supporting bulkhead, but springs clear, the weir is a sharp-crested weir
(USBR, 2001). A broad-crested weir is a flatcrested structure with a crest length large compared to the flow thickness. The ratio of crest length to upstream head over crest must be typically greater than 3 (Henderson, 1966; Chanson, 2004). The flow control section can have different shapes, such as rectangular, triangular, trapezoidal or circular. Labyrinth weirs are those for which the weir crest is not straight in planform (Wormleaton and Soufiani, 
1998). The increased crest length of labyrinth weirs gives them the clear advantage of reducing upstream levels for a particular discharge over low head ranges (Wormleaton and Tsang, 2000). The flow over weirs would be classified as a free jet, as shown in Figs. 1a-c) and Figs. 2a, b).

Weirs have a large number of uses in engineering applications. Listing the more usual, these are: 1. to measure the flow of water in small stream and constructed channels; 2 . to regulate the flow of water in open channel and reservoir; 3 . to take the water for irrigation systems; 4. to divert flow during high flow conditions in sewer systems; 5 . to increase the dissolved oxygen content of the water by mean of aeration the water; 6 . to reduce tastes and odors caused by dissolved gases in the water by mean of aeration the water, such as hydrogen sulphide, which are then released; and also to oxidize and remove organic matter; 7 . to decrease the carbon dioxide content of a water by mean of aeration the water and thereby reduce its corrosiveness and raise its $\mathrm{pH}$ value; 8 . to remove certain volatile organic compounds by mean of aeration the water.

An overflow jet that plunges into a channel after passing through a gas phase entrains a substantial amount of air into the receiving pool, and forms a submerged two-phase region with a considerable interfacial area. Almost all the mass transfer substantially takes place in this two-phase region. Therefore, maximum penetration depth of the bubble swarm is one of the most important parameters that characterize the performance of weir aeration system and the design of downstream receiving pool. Moreover, estimating flow characteristics of weirs would be useful for scour depth in the downstream receiving channel because flow characteristics of the weirs are different from each other.

Apted and Novak (1973), Avery and Novak (1978), and Nakasone (1987) reported that tailwater depth was an important weir operation parameter, influencing mass transfer. Tailwater depth is also an important parameter for energy dissipation and scouring cases. Grindrod (1962) and Albrecht (1968) pointed out that the aeration efficiency would increase with increasing tailwater depth. However, there should be a limit because the penetrating air bubbles will not go to infinite depths. Actually, for each combination of discharge, drop height, and weir type, there would be an approximate maximum depth to which the bubbles would penetrate, thus limiting the aeration efficiency. Studies by Nakasone $(1975,1976$, and 1987) contributed substantially to the experimental investigations of the weir aeration. Nakasone (1987) did not investigate the case whether or not air bubbles reached the floor of the stilling basin. For tailwater depth, Nakasone suggested to adapt as $2 / 3$ of drop height. However, the bubble penetration depth and the overfall jet expansion would be different for each weir type and shape and it would not be true to give the bubble penetration depth as a function of only drop height. Moreover, the bubble penetration depth differs from each weir type.

Kobus and Koschitzky (1991) presented the empirical correlation for penetration depth $D_{p}=0.00433 \operatorname{Re}_{j}^{0.39} F_{j}^{0.24}$, where $\operatorname{Re}_{j}-$ jet Reynolds number, $\operatorname{Re}_{j}=\frac{q_{j}}{v}$ and $\mathrm{F}_{j}-$ the jet Froude number, $F_{j}=\left[\frac{\mathrm{g} h^{3}}{2 q_{j}^{2}}\right]^{1 / 4}$. Nakasone (1987) advised that the receiving pool depth $D_{p}$ ceases to affect aeration efficiency when it exceeds two-thirds of the drop height $h$ (i.e., $D_{p} \geq 2 / 3 h$ ), and Avery and Novak (1978) gave the relationship as $D_{p} \geq 7.5 h^{0.58} \mathrm{~F}_{j}^{-0.53}$, where $h$ - drop height and $\mathrm{F}_{j}$ - the jet Froude number.

Kumagai et al. (1993), Clanet and Lasheras (1997), and Ito et al. (2000) studied depth of penetration of bubbles entrained by a plunging water jet. They presented correlations for predicting the bubble penetration depth of plunging water jet as a function of the operational conditions and nozzle geometry. Baylar and Emiroglu (2002), and Emiroglu and Baylar (2003 and 2005) studied air entrainment rate of the broad crested, sharp crested weirs and labyrinth weirs and they stated that weir shape is very sensitive for flow characteristics. The behavior of water flowing over a weir varies significantly with weir shape and type. It is therefore highly desirable to investigate flow characteristics for different weir types and their shapes.

This paper presents an experimental investigation of the bubble penetration depth $D_{p}$, trajectory of free overfall nappe from the weirs, the length of the bubble zone, and the overfall jet expansion $J_{e}$ of the sharp crested weirs, broad crested weirs, and labyrinth weirs. In addition, the paper studies most efficient length, width and depth of the downstream receiving pool for especially weir aerators.

\section{Dimensional analysis}

The functional relationship involving the maximum bubble penetration depth and influencing variables can be written as 


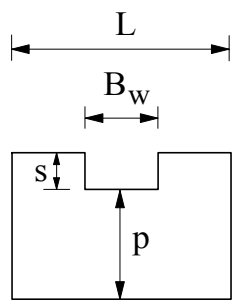

Rectangular weir

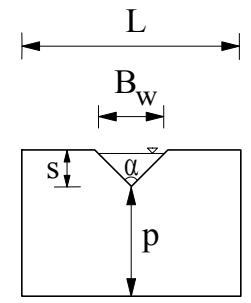

Triangular weir
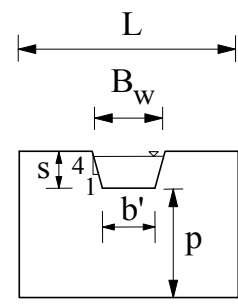

Trapezoidal weir

a)
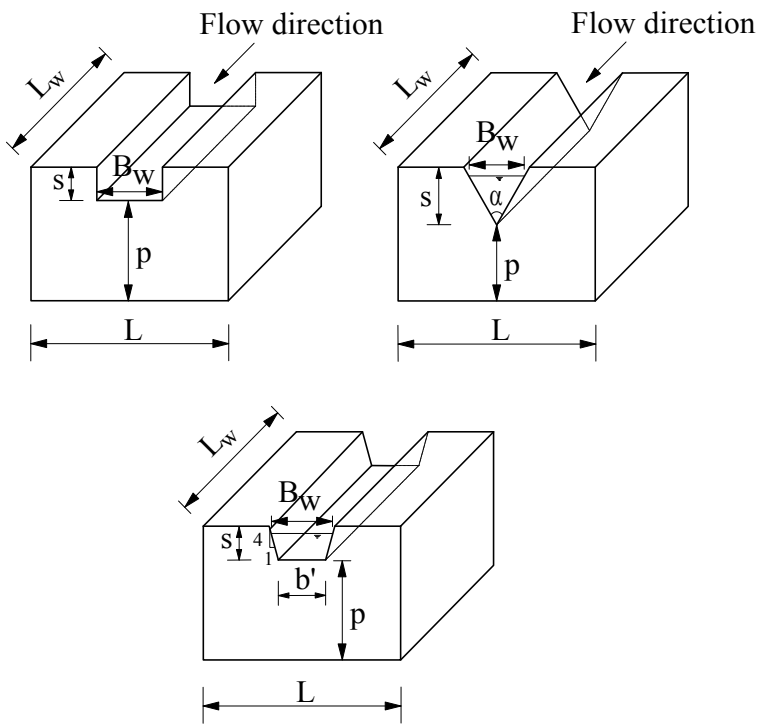

b)

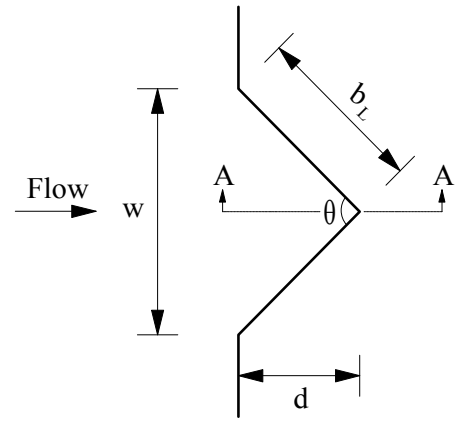

Plan view

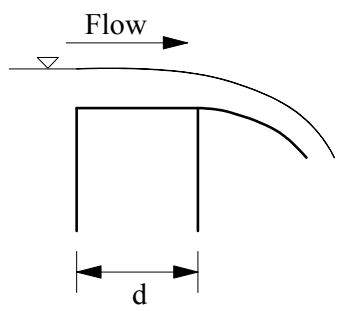

A-A cross-section

c)

Fig. 1. Weirs; a) Sharp-crested weir, b) Broad-crested weir, c) Labyrinth weir. Obr. 1. Priepady; a) ostrohranné; b) so širokou korunou; c) labyrintové. 


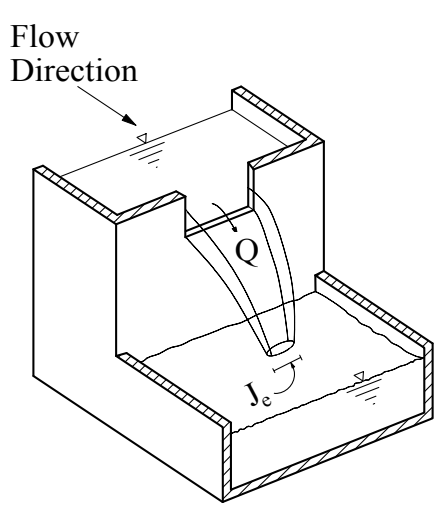

(a) Straight Weir
Flow

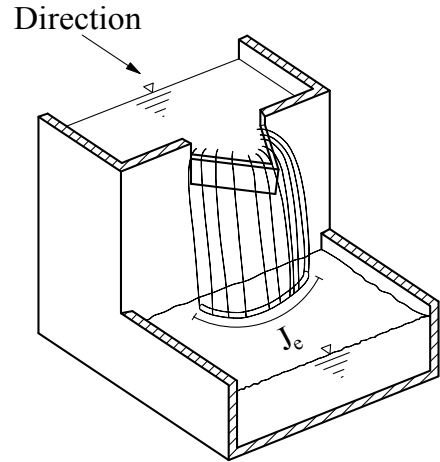

(b) Triangular Labyrinth Weir

Fig. 2. Sketch of flow patterns of free jet over weirs; a) Rectangular sharp-crested weir; b) Labyrinth weir. Obr. 2. Náčrt vol’ného prúdu nad priepadom; a) pravouhlý, ostrohranný, b) labyrintový priepad.

$D_{p}=f_{1}\left(\begin{array}{l}\Delta H, B_{w}, q_{j}, \rho, \Delta \rho, \mathrm{g}, \mu \\ \sigma, P_{o n}, \Delta P, z, b_{r}, b_{\ell}, b_{d}, b_{u}\end{array}\right)$,

in which $D_{p}-$ maximum bubble penetration depth, $\Delta H$ - energy difference between the flow over the weir crest and the receiving pool, $B_{w}$ - water surface width over the crest of the weir, $q_{j}$ - discharge through the per unit water surface width at the crest of the weir $\left(q_{j}=Q / B_{w} ; Q-\right.$ total discharge through the weir), $\rho$-density of fluid (water), $\Delta \rho=\rho-\rho_{a}$, $\rho_{a}$ - density of gas (air), g - gravity acceleration, $\mu$ - viscosity of the fluid (water), $\sigma$ - surface tension of the fluid (water), $P_{\text {on }}$ - ambient pressure on the outer nappe of the jet, $P_{u n}-$ ambient pressure on the lower nappe of the jet (under the nappe), $\Delta P=\left(P_{\text {on }}-\right.$ $\left.-P_{u n}\right), z$ - depth of flow in the receiving pool, $b_{r}, b_{\ell}, b_{u}, b_{d}$ - the distances of the right side, left side, upstream and downstream walls of the receiving pool to the center point of the jet where it impacts the water surface in the receiving pool, respectively as shown in Fig. $3 \mathrm{a}-\mathrm{c}$ ).

Note that $\Delta H=h+H_{w}+v_{o}^{2} / 2 g$, in which $h-$ vertical height of the weir crest with respect to the water surface level in the receiving pool (i.e., drop height), $H_{w}$ - the vertical difference between the water surface in the upstream pool and the weir crest, $v_{o}$ - average flow velocity in the upstream pool. It is well known that if $H_{w}$ is measured at a distance sufficiently for upstream of the weir (i.e., more than $\left.4 H_{w}\right), v_{o}^{2} / 2 \mathrm{~g}$ is generally negligible. Therefore one can take

$$
\Delta H=h+H_{w} .
$$

It should be mentioned here that the air entrainment in a jet highly depends on the shear hence velocity, between the surface of the free jet (nappe) and air. Also, the fluid and flow conditions about the bubble cloud within the receiving pool are very complex. Due to these reasons, the average flow velocity may not be that good influencing factor to be chosen the dimensional analysis. The average flow velocity may cause under estimation of the quantities. This is why, the discharge per unit water surface width $\left(q_{j}=Q / B_{w}\right)$ is preferred to the average flow velocity as an influencing variable in the dimensional analysis. The dimensional analysis in Eq. (1) yields,

$\frac{D_{p}}{\Delta H}=f_{1}\left[\begin{array}{c}F_{j}, \mathrm{Re}_{j}, W, E_{u}, \frac{z}{B_{w}}, \frac{b_{r}}{B_{w}}, \\ \frac{b_{\ell}}{B_{w}}, \frac{b_{d}}{B_{w}}, \frac{b_{u}}{B_{w}}, \frac{\Delta P}{P_{o n}}\end{array}\right]$,

in which, $\mathrm{F}_{j}-$ jet Froude number $=\left[\frac{\mathrm{g} h^{3}}{2 q_{j}^{2}}\right]^{1 / 4}$,

$\operatorname{Re}_{j}-$ jet Reynolds number $=\frac{q_{j}}{v} \quad(v=\mu / \rho)$,

$\mathrm{W}-$ jet Weber number $=\frac{\rho q_{j}^{2}}{B_{w} \sigma}$ and

$E_{u}=$ jet Euler number $=\frac{q_{j}}{B_{w} \sqrt{\frac{\Delta \rho}{\rho}}}$. 


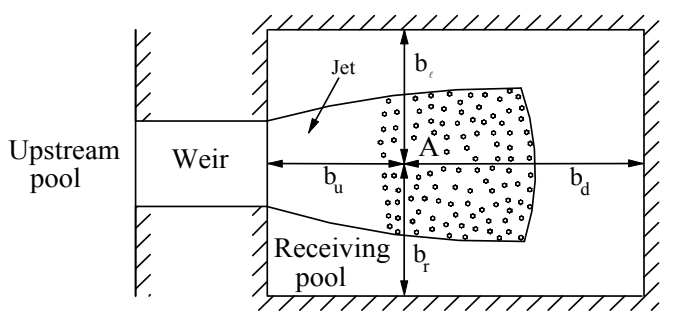

(a) Plan

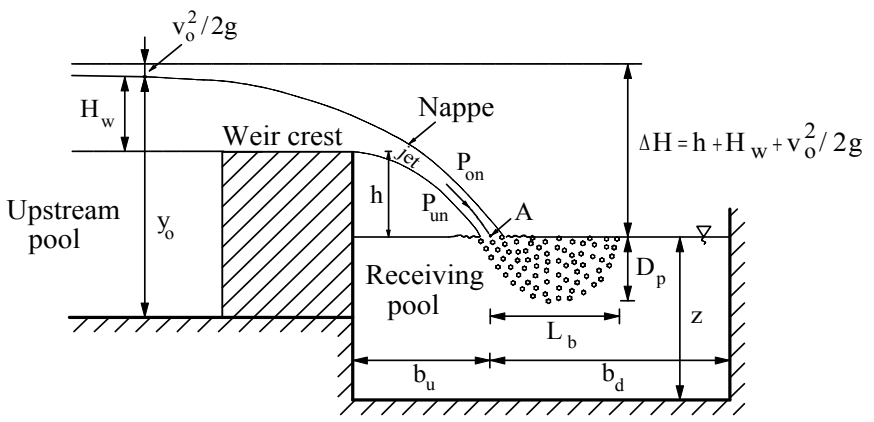

(b) Cross-Section

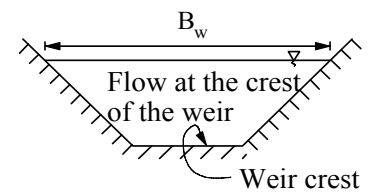

(c) Trapezoidal Weir, Cross-Section

Fig. 3. Receiving pool; a) Plan, b) Cross-section, c) Trapezoidal weir, Cross-section. Obr. 3. Vývar; a) nákres; b) priečny rez, c) lichobežníkový priepad, priečny rez.

In this study, since the jet nappe is freely ventilated and open into atmosphere and no clinging of the nappe onto the weirs, $\Delta P / P_{o n}$ has no physical importance and keeping in mind the scale effects, the effect of Weber and Euler number are negligible in air entrainment problems (Kells and Smith, 1991). Thus, under these reasons Eq. (1) becomes,

$\frac{D_{p}}{\Delta H}=f_{1}\left[F_{j}, \operatorname{Re}_{j}, \frac{z}{B_{w}}, \frac{b_{r}}{B_{w}}, \frac{b_{\ell}}{B_{w}}, \frac{b_{d}}{B_{w}}, \frac{b_{u}}{B_{w}}\right]$,

$\frac{D_{p}}{\Delta H}=f_{1}\left[F_{j}, \operatorname{Re}_{j}\right]$.

If one conducts the similar dimensional analysis for $L_{b}$ - length of the bubble zone; $b_{u}$ - horizontal distance of the jet impact point at the water surface in the receiving pool and to the upstream back wall, one gets
$\frac{L_{b}}{\Delta H}=f_{2}\left[F_{j}, \operatorname{Re}_{j}, \frac{z}{B_{w}}, \frac{b_{r}}{B_{w}}, \frac{b_{\ell}}{B_{w}}, \frac{b_{d}}{B_{w}}, \frac{b_{u}}{B_{w}}\right]$,

$\frac{L_{b}}{\Delta H}=f_{2}\left[F_{j}, R e_{j}\right]$,

$\frac{b_{u}}{\Delta H}=f_{3}\left[F_{j}, \operatorname{Re}_{j}\right]$,

$\frac{J_{e}}{\Delta H}=f_{4}\left[F_{j}, \operatorname{Re}_{j}\right]$.

Note that since $D_{p}, L_{b}, b_{u}$ and $J_{e}$ are just before the impact of the jet at the water surface they are independent of $z, b_{r}, b_{\ell}, b_{d}$ and $b_{u}$ as shown in Eqs. (5), (7), (8) and (9). 


\section{Air Entrainment mechanisms-classification and break-up length of the jets}

Tsang (1987) described four basic air entrainment mechanisms with reference to a free falling jet from a weir. Tsang's four air entrainment mechanisms are smooth, rough, oscillating, and disintegrated. For small drop heights, a water jet with a relatively smooth surface issues from the weir. The major source of air supply is visualized as a thin layer surrounding the jet and carried into the water upon impact, and therefore the air entrainment capacity is limited. The water surface in the receiving pool is relatively undisturbed. As the drop height increases, the surface of the jet becomes roughened. The air supply can be considered as coming largely from small air pockets entrapped between the jet surface roughness and the receiving water. At impact, the jet produces ripples on the pool surface. Compared with the smooth jet under similar conditions, this mechanism results in shallower bubble penetration but increased entrainment rate, because the bubbles are more densely packed in the biphasic zone. As the drop height is increased further, the jet begins to oscillate during the fall. The primary air source originates from large air pockets entrapped between the undulating jet and the pool surface. The pool surface is considerably agitated, and air may also be entrained by surface roller action and splashing. Large air pockets are transported from the surface into the water depth and broken down due to turbulence. With an even larger drop height, the jet breaks up into discrete droplets. The pool surface is intensely agitated, and air is entrained by the action of surface rollers and by the engulfing of air pockets as jet fragments hit the pool surface. The bubbles are generally only transported to relatively shallow depths. Disintegrated jets have the advantage over solid jets of greater surface area; however, air entrainment rate $Q_{A}$ and bubble penetration are significantly reduced because of energy loss to the surrounding atmosphere during the fall (Wormleaton and Tsang, 2000).

The break-up length $L_{b r}$ at which the jet begins to disintegrate can be determined using Horeni's Equation for rectangular jets $L_{b r}=31.19 q_{w}^{0.319}$, where $L_{b r}$ is the break-up length [cm] and $q_{w}$ is the specific flow over the weir in $\mathrm{cm}^{3} \mathrm{~s}^{-1} \mathrm{~cm}^{-1}$. On the other hand, the equation of the break-up length for rectangular jet, established by Castillo (2007) is
$\frac{L_{b r}}{B_{i} F_{i}^{2}}=\frac{0.85}{\left(1.07 T_{u} F_{i}^{2}\right)^{0.82}}$,

where $B_{i}$ and $\mathrm{F}_{i}$ are the jet thickness and Froude number at issuance conditions, respectively. $T_{u}$ is the initial turbulence intensity when the flow passes on spillway $\left(0 \leq T_{u} \leq 3 \%\right)$.

\section{Experimental equipment and procedure}

Fig. 4 shows the laboratory arrangement for the current study. The experiments have been conducted in a rectangular flume with glass sides and well painted steel bed. The flume is $3.40 \mathrm{~m}$ in length, $0.6 \mathrm{~m}$ in width, and $0.6 \mathrm{~m}$ in depth and the bed has an average Manning's roughness coefficient $\bar{n}$ of 0.0099 . A digital point gauge has been mounted on rails along the channel allowed the upstream water surface profile, then the nappe profile, and $H_{w}$ have been measured. Furthermore, a digital point gauge has been mounted on the received pool to measure $h$. The water in the experimental channel has been re-circulated by a pump. The water jet from the test weir has plunged into a downstream water pool, whose height is adjusted using a release valve. The plan-view dimensions of the downstream water pool made of glasswall are $1.75 \mathrm{~m}$ in length, $1.50 \mathrm{~m}$ in width, and $2 \mathrm{~m}$ in height.

The experiments reported here are carried out with rectangular sharp-crested weirs $\left(B_{w}=0.10\right.$, 0.20 and $0.30 \mathrm{~m}$ ), trapezoidal sharp-crested weir (Cipolletti weir with $1 \mathrm{H} / 4 \mathrm{~V}, \mathrm{~b}^{\prime}=0.20 \mathrm{~m}$ and, $L_{w}=$ $0.40 \mathrm{~m})$, triangular sharp-crested weirs $\left(\alpha=30^{\circ}\right.$, $60^{\circ}, 90^{\circ}$ and $\left.120^{\circ}\right)$, triangular labyrinth weirs $(\theta=$ $45^{\circ}, 90^{\circ}$ and $135^{\circ}$ ) all having the same total sill length of $0.30 \mathrm{~m}$, rectangular broad-crested weirs $\left(B_{w}=0.10,0.20\right.$ and $0.30 \mathrm{~m}$ and, $\left.L_{w}=0.40 \mathrm{~m}\right)$, trapezoidal broad-crested weir $\left(1 \mathrm{H} / 4 \mathrm{~V}, b^{\prime}=0.20\right.$ and, $\left.L_{w}=0.40 \mathrm{~m}\right)$, triangular broad-crested weirs $(\alpha$ $=30^{\circ}, 60^{\circ}, 90^{\circ}$ and $120^{\circ}$ and, $L_{w}=0.40 \mathrm{~m}$ ), as can be seen in Figs. 1a-c). The difference between crest and top in all weirs $s$ is $0.25 \mathrm{~m}$ and crest height $p$ is $0.35 \mathrm{~m}$. Each weir configuration has been tested under flow rates $Q$ varying from 1.0 to $5.0 \mathrm{~L} \mathrm{~s}^{-1}$ in 1 $\mathrm{L} \mathrm{s}^{-1}$ steps. The drop height $h$, defined as the difference between the water levels upstream and downstream of the weir, is varied between 0.20 to $1.00 \mathrm{~m}$ in $0.20 \mathrm{~m}$ steps.

Penetration depth, $D_{p}$, of the bubbles produced by the jet, which is defined as the vertical distance from the water surface to the lower end of the submerged biphasic region in the water. Penetration 
depth is measured by a movable scale from the receiving pool wall. This scale is capable of reading to the nearest $1.0 \mathrm{~mm}$. All measurements are repeated three times and then averaged, especially for penetration depth measurements. In all of the experiments, the tailwater depth is selected greater than the maximum bubble penetration depth so that bubbles cannot reach the floor of the downstream water pool. The expansion measured at impact point on the liquid pool of free overfall jet is named as jet expansion, $J_{e}$. And, it is measured by a scale which is capable of reading to the nearest $0.5 \mathrm{~mm}$. The length, $L_{b}$, shown in Fig. 3a) is named as the length of the bubble zone. Also, it is measured by a scale which is capable of reading to the nearest 1.0 $\mathrm{mm}$. A total of 675 tests are performed in this study.

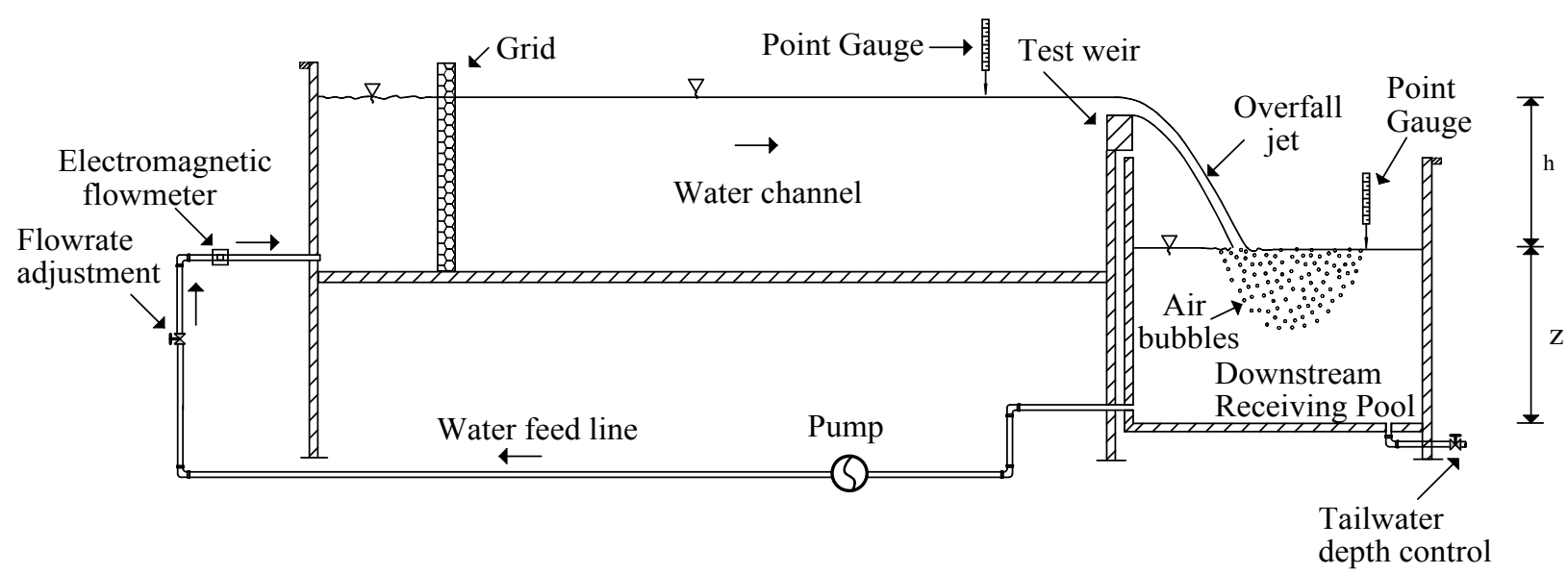

Fig. 4. Experimental apparatus.

Obr. 4. Aparatúra.

\section{Evaluation of experimental results}

For different weir types, the bubble penetration depth $D_{p}$, the overfall jet expansion $J_{e}$, the length of the bubble zone $L_{b}$, and the horizontal distance to overfall jet impact point from the weir $b_{u}$ are determined for a range of discharges and drop heights. The following sections present and discuss the experimental results.

To examine the effect of weir types on the overfall jet expansion, $J_{e}$ values are plotted against drop height. The experimental data are presented in Fig. 5. The overfall jet expansion of the weirs is highly different from each other. The experimental data indicate that the overfall jet expansion increases with an increasing water discharge. As shown in Fig. 5, the labyrinth weirs have the highest values of overfall jet expansion among weirs tested. At labyrinth weirs, the overfall jet expansion increases as the included angle in the triangular labyrinth weirs decreases. Overfall jet expansion at the labyrinth weirs is significantly more than the trapezoidal sharp-crested weir, the rectangular sharp- crested weirs, and circular sharp-crested weir. This is due to the fact that the labyrinth weirs have more crest length than the other weirs tested. The overfall jet expansion of the labyrinth weirs show an increasing tendency when drop height increases. But, the tendency of overfall jet expansion for the trapezoidal sharp-crested weir, the rectangular sharpcrested weirs slightly show a decrease as drop height increases, as illustrated in Fig. 5. The results indicate that the trapezoidal sharp-crested weir and the rectangular sharp-crested weirs have the lowest overfall jet expansion values. At the rectangular sharp-crested weirs, the overfall jet expansion increases with an increasing crest width $B_{w}$. It can be seen from the Fig. 5 that overfall jet expansion for the rectangular broad-crested weirs is more than the rectangular sharp-crested weirs. For triangular sharp-crested weirs, the overfall jet expansion increases as the angle of triangular weirs $\alpha$ decreases. Fig. 5 shows that overfall jet expansion for the triangular broad-crested weirs is significantly less than the triangular sharp-crested weirs. 


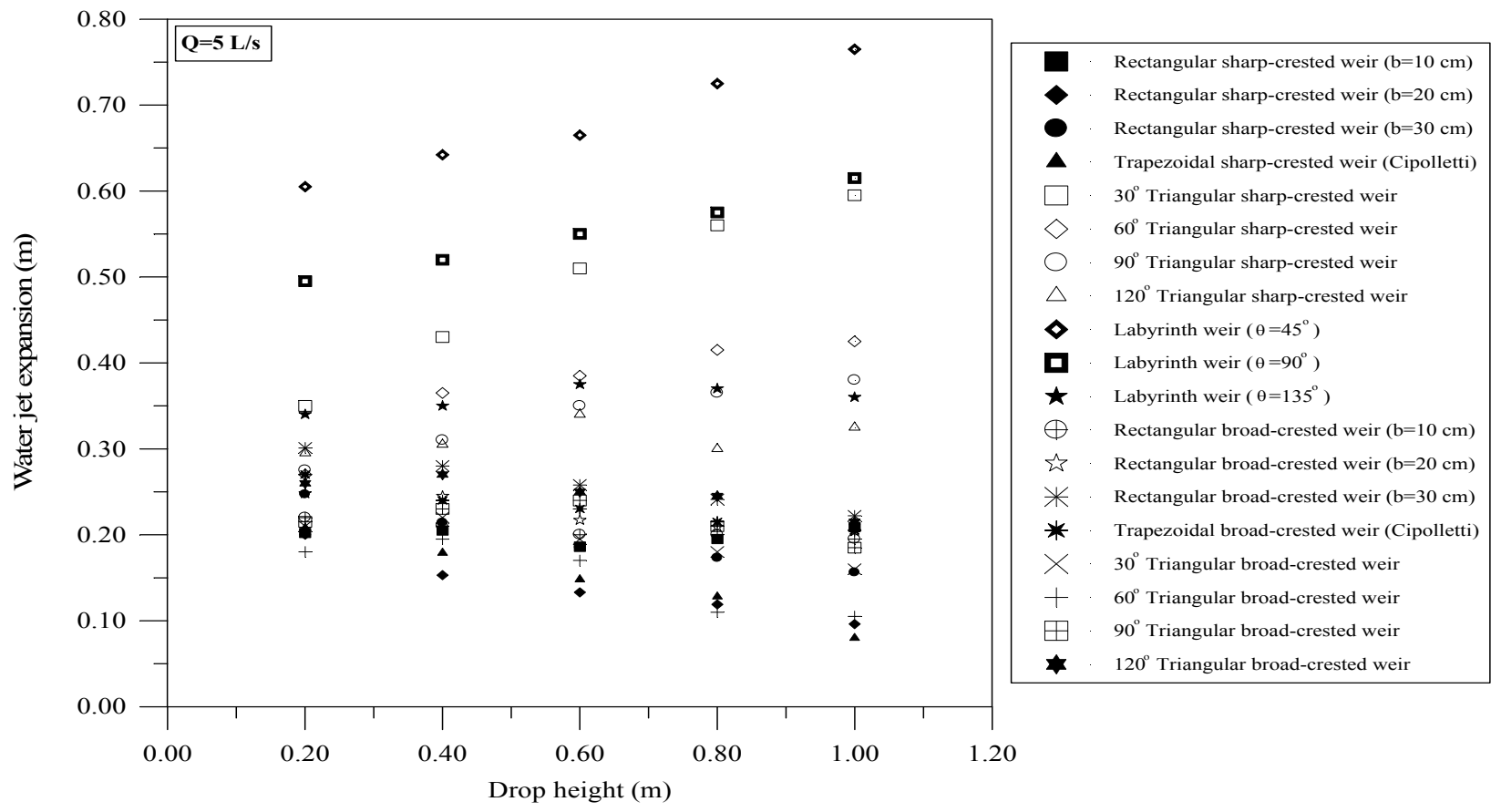

Fig. 5. Variation in overfall jet expansion of different weir types with drop height for $Q=5 \mathrm{~L} \mathrm{~s}^{-1}$. Obr. 5. Variácie rozšírenia prepadového prúdu rozdielnych typov priepadov s výškou $Q=5 \mathrm{~L} \mathrm{~s}^{-1}$.

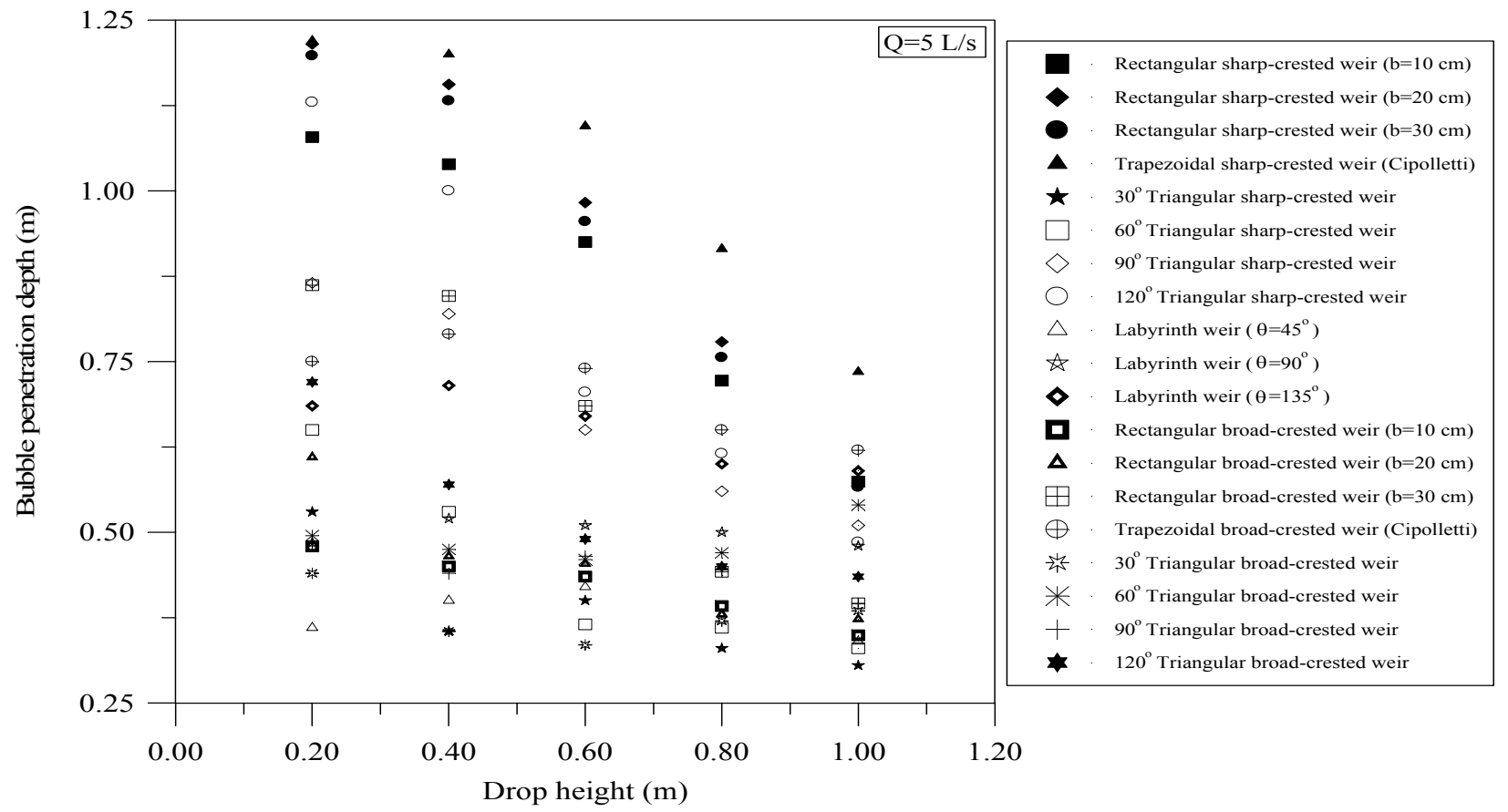

Fig. 6. Variation in penetration depth of different weir types with drop height for $Q=5 \mathrm{~L} \mathrm{~s}^{-1}$.

Obr. 6. Variácie híbky prieniku vzduchových bublín rozdielnych typov priepadov s výškou $Q=5 \mathrm{~L} \mathrm{~s}^{-1}$. 
The residence time of entrained air bubbles in a water body directly affects the oxygen mass transfer. This residence time is related to the bubble flow path and hence $D_{p}$ into the receiving water. It is observed from experimental data that bubble penetration depth is closely related to the jet shape and expansion that is unique to each weir type.

The bubble penetration depth of the weirs is also highly different from each other. It would not be true to give the bubble penetration depth as a function of only drop height. Fig. 6 shows variation in $D_{p}$ of nineteen different weir types with drop height while the change in discharge is constant. Experiments with all nineteen weirs indicate that the weir type and shape, the water discharge, and the drop height are important factors influencing $D_{p}$. It is found from these results that $D_{p}$ tends to increase with water discharge $Q$. It is clear from the results in Fig. 6 that $D_{p}$ generally decreases with increasing drop height. The experimental results show that $D_{p}$ decreases with increasing overfall jet expansion $J_{e}$. The decrease in $D_{p}$ with increasing in $J_{e}$ is might be due mainly to the increased buoyant forces of the entrained bubbles as a result of the increase in the air entrainment rate, which may have caused by the increase of the jet surface roughness.

As is seen from Fig. 6, the labyrinth weirs have the lowest values of bubble penetration depth among the weirs tested. It can be seen from the experimental results that $D_{p}$ values for triangular labyrinth weir with included angle of $45^{\circ}$ are observed the lowest at all discharge, from 1 to $5 \mathrm{~L} \mathrm{~s}^{-1}$. The rectangular and trapezoidal sharp-crested weirs are observed to have the highest bubble penetration depth among all weirs tested (Fig. 6). Especially, the trapezoidal sharp-crested weir has the highest bubble penetration depth, $D_{p}$, values. Moreover, at both triangular sharp-crested weirs and triangular broad-crested weirs, it is demonstrated that $D_{p}$ increased as the angle of $\alpha$ in triangular weirs increased.

It may be concluded from Fig. 5 and Fig. 6 that $D_{p}$ decreases while the overfall jet expansion increases. Thus, the scour depth in the downstream channel would decrease with increasing the overfall jet expansion because the bubble penetration depth would decrease. Moreover, overfall jet's momentum is sensitive for aeration. It can be seen from these two figures that if drop height is highly increased, then the overfall jet is disintegrated and the bubble penetration depth is much decreased. At this state, the aeration performance of the weirs would be extremely little.
Fig. 7 shows the relationship between $D_{p}$ and $h$ with Kobus and Koschitzky's results; Avery and Novak's results and present study data when the weir type is rectangular broad crested weir. Good agreement between the measured values and the values computed from the Kobus and Koschitzky's, and Avery and Novak's equations are obtained.

Scimeni (1937) expressed the shape of the nappe in co-ordinates $\mathrm{x}$ and $\mathrm{y}$, measured from an origin at the highest point, for a unit value of $H$ as $y=K x^{n} H^{1-n}$, where $K=0.5$ and $n=1.85$. These values are taken as $K=0.47$ and $n=1.80$ for Creager profile. Thus, the lower jet trajectory can define with $y=0.50 x^{1.85} \cdot H^{-0.85}$ and $y=0.47 x^{1.80} \cdot H^{-0.80}$ (Scimemi, 1930; Scimemi, 1937; Creager et al., 1945). Where $x, y$ coordinates and $H$ is equal to $H_{w}$ $+v_{o}{ }^{2} / 2 \mathrm{~g}$. Nowadays most crests have an ogee shape, (e.g. Scimemi profile, Creager profile).

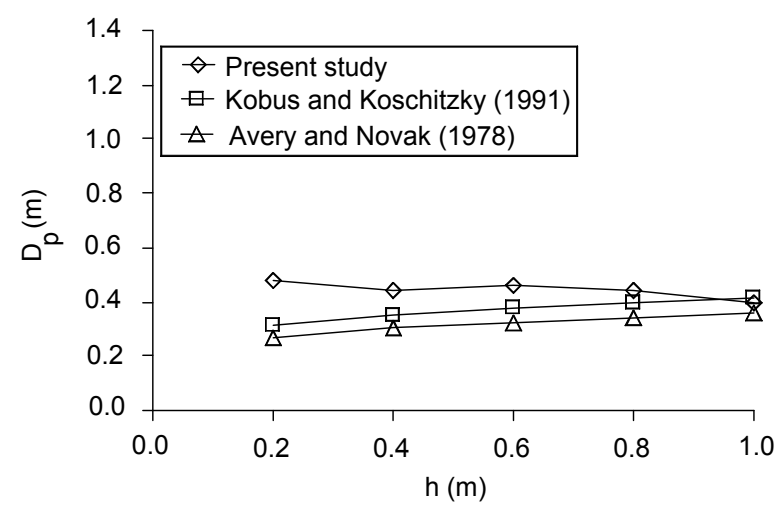

Fig. 7. Comparison of the $D_{p}$ values of rectangular broad crested weir with the equations of Kobus and Koschitzky (1991), and Avery and Novak (1978).

Obr. 7. Porovnanie hodnôt $D_{p}$ pravouhlého priepadu so širokou hranou s výsledkami podl'a rovníc Kobusa a Koschitzkého (1991), a Avery, Novaka (1978).

Fig. 8 shows the jet trajectories for different weir types tested. Equations for the jet trajectory of weirs other than rectangular sharp-crested weir do not exist in literature as far as I know. But, free jet trajectory equations for an open channel, a flip bucket, an orifice through a dam and an overtopping dam crest exist in literature (Davis et al., 1999; Dey, 2002; Wahl et al., 2008). Therefore, present study data are compared with Scimemi and Creager profiles (Fig. 9). Good agreement between the present study $b_{u}$ values and the values computed from the Scimemi and Creager equations is obtained.

The nature of the nappe affects significantly the aeration mechanism due to bubble behavior. There- 
fore, the jet break-up was considered in this experimental study. The break-up length $L_{b r}$ was calculated using Horeni's and Castillo's equations and, the $L_{b r}$ values for the experimental data were obtained between $120 \mathrm{~cm}$ to $250 \mathrm{~cm}$. Castillo stated that the Horeni's formula gives correct values for flows smaller than $q_{w}=0.25 \mathrm{~m}^{2} \mathrm{~s}^{-1}$. The jet breakup was not observed in the study because maximum drop height was taken as $100 \mathrm{~cm}$. This situation was confirmed with Horeni's and Castillo's equations.

Empirical correlations predicting the overfall jet expansion $J_{e}$, the bubble penetration depth $D_{p}$,

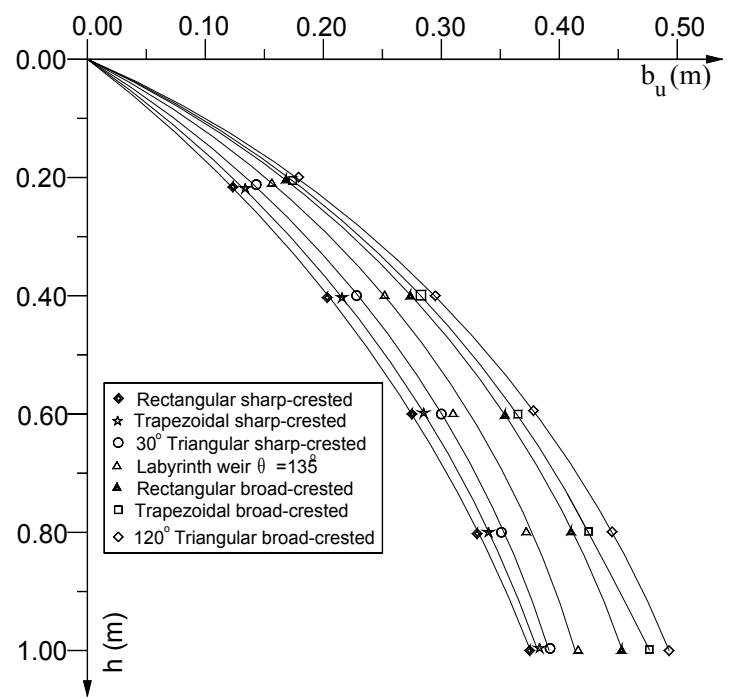

the distance between the channel intake and the overfall jet impact point $b_{u}$, and the length of the bubble zone $L_{b}$ are developed for the weirs. The resulting correlations are given in Eqs. (11)-(14) and the values of constants in these correlations are shown in Tabs. 1-4.

$$
\begin{aligned}
& \frac{D p}{\Delta H}=A \cdot\left[\ln \left(B \cdot \operatorname{Re}_{j}^{a_{1}} \cdot F_{j}^{a_{2}}\right)\right]^{a_{3}}, \\
& \frac{L_{b}}{\Delta H}=A \cdot\left[\ln \left(B \cdot \operatorname{Re}_{j}^{a_{1}} \cdot F_{j}^{a_{2}}\right)\right]^{a_{3}}, \\
& \frac{J_{e}}{\Delta H}=A \cdot\left[\ln \left(B \cdot \operatorname{Re}_{j}^{a_{1}} \cdot F_{j}^{a_{2}}\right)\right]^{a_{3}}, \\
& \frac{b_{u}}{\Delta H}=A \cdot\left[\ln \left(B \cdot \operatorname{Re}_{j}^{a_{1}} \cdot F_{j}^{a_{2}}\right)\right]^{a_{3}},
\end{aligned}
$$

where $J_{e}$ - the overfall jet expansion [m], $D_{p}$ - the penetration depth [m], $b_{u}$ - the distance between the channel intake and the overfall jet impact point [m], $L_{b}$ - the length of the bubble zone [m], $H$ - the drop height $[\mathrm{m}], Q-$ the water discharge $\left[\mathrm{m}^{3} \mathrm{~s}^{-1}\right], B_{w}-$ the crest width in rectangular sharp and broadcrested weirs $[\mathrm{m}], \alpha$ - the angle in triangular sharp and broad-crested weirs $\left[^{\circ}\right], \theta$ - the included angle in triangular labyrinth weirs $\left[^{\circ}\right]$.

Fig. 8. Jet trajectories for the different weir types.

\begin{tabular}{|c|c|c|c|c|c|c|}
\hline Weir Type & $\mathrm{A}$ & B & $a_{1}$ & $a_{2}$ & $a_{3}$ & $\varepsilon[\%]$ \\
\hline $\begin{array}{l}\text { Sharp-crested } \\
\text { triangular }{ }^{1)}\end{array}$ & $0.421^{\cos \alpha}$ & 2.353 & 0.009 & 0.032 & -48.10 & 5.2 \\
\hline $\begin{array}{l}\text { Sharp-crested } \\
\text { rectangular }^{2}\end{array}$ & 4.369 & 68.90 & -0.264 & -0.583 & 1.523 & 6.5 \\
\hline $\begin{array}{l}\text { Sharp-crested } \\
\text { trapezoidal }^{3)}\end{array}$ & 7.706 & 15.805 & -0.163 & -0.392 & 1.629 & 4.6 \\
\hline $\begin{array}{l}\text { Broad-crested } \\
\text { triangular }\end{array}$ & $\mathrm{F}_{j}^{-0.612} 0.706^{\cos \alpha}$ & 0.72 & 0.100 & 0.108 & -5.046 & 6.7 \\
\hline $\begin{array}{l}\text { Broad-crested } \\
\text { rectangular' }\end{array}$ & $\ln \left(\mathrm{F}_{j}^{1.977}\right)$ & 14.649 & -0.140 & -0.311 & 5.933 & 5.5 \\
\hline $\begin{array}{l}\text { Broad-crested } \\
\text { trapezoidal }^{6)}\end{array}$ & 0.859 & $\exp (7.151)$ & -0.406 & -1.000 & 1.871 & 5.5 \\
\hline $\begin{array}{l}\text { Triangular } \\
\text { labyrinth }^{7)}\end{array}$ & $0.724^{\cos \theta}$ & 0.945 & 0.064 & 0.241 & -5.717 & 8.1 \\
\hline
\end{tabular}

Obr. 8. Trajektórie prúdu rozdielnych typov priepadov.

T a b l e 1. Values of constants $\left(D_{p}\right)$ in Eq. (10).

$\mathrm{T}$ a b u l'k a 1 . Hodnoty konštánt $\left(D_{p}\right)$ v rov. (10).

${ }^{1)}$ ostrohranný trojuholníkový priepad, ${ }^{2)}$ ostrohranný pravouhlý priepad, ${ }^{3)}$ ostrohranný lichobežníkový priepad, ${ }^{4)}$ trojuholníkový priepad so širokou hranou, ${ }^{5}$ pravouhlý priepad so širokou hranou, ${ }^{6}$ lichobežníkový priepad so širokou hranou, ${ }^{71}$ trojuholníkový labyrintový priepad. 
T a b l e 2. Values of constants $\left(L_{b}\right)$ in Eq. (11).

$\mathrm{T}$ a b u l'k a 2 . Hodnoty konštánt $\left(L_{b}\right)$ v rov. (11).

\begin{tabular}{lcccccc}
\hline Weir Type & $\mathrm{A}$ & $\mathrm{B}$ & $\mathrm{a}_{1}$ & $\mathrm{a}_{2}$ & $\mathrm{a}_{3}$ & $\varepsilon[\%]$ \\
\hline $\begin{array}{l}\text { Sharp-crested } \\
\text { triangular }\end{array}$ & $\mathrm{Re}_{j}^{0.394} 0.414^{\cos \alpha}$ & 1.979 & -0.035 & -0.097 & 2.233 & 4.7 \\
$\begin{array}{l}\text { Sharp-crested } \\
\text { rectangular }\end{array}$ & $\mathrm{Re}_{j}^{0.304}$ & 1.580 & -0.030 & -0.061 & 1.000 & 9.6 \\
$\begin{array}{l}\text { Sharp-crested } \\
\text { trapezoidal }\end{array}$ & $\ln \left(\mathrm{Re}_{j}^{0.165}\right)$ & 1.084 & 0.059 & 0.243 & -6.248 & 12.3 \\
$\begin{array}{l}\text { Broad-crested } \\
\text { triangular) }\end{array}$ & $0.449^{\cos \alpha}$ & 4.201 & -0.001 & -0.258 & 5.719 & 4.8 \\
$\begin{array}{l}\text { Broad-crested } \\
\text { rectangular }\end{array}$ & 3.215 & 7.02 & -0.075 & -0.216 & 5.866 & 6.9 \\
$\begin{array}{l}\text { Broad-crested } \\
\text { trapezoidal }\end{array}$ & $\ln \left(\mathrm{Re}_{j}^{0.028}\right)$ & 1.001 & 0.046 & 0.193 & -6.067 & 8.1 \\
$\begin{array}{l}\text { Triangular } \\
\text { labyrinth }\end{array}$ & $1.079^{\cos \alpha}$ & 1.809 & -0.033 & 0.466 & -2.580 & 5.8 \\
\hline
\end{tabular}

${ }^{1)}$ ostrohranný trojuholníkový priepad, ${ }^{2)}$ ostrohranný pravouhlý priepad, ${ }^{3)}$ ostrohranný lichobežníkový priepad, ${ }^{4)}$ trojuholníkový priepad so širokou hranou, ${ }^{55}$ pravouhlý priepad so širokou hranou, ${ }^{6}$ lichobežníkový priepad so širokou hranou, ${ }^{7)}$ trojuholníkový labyrintový priepad.

$\mathrm{T}$ a b 1 e 3. Values of constants $\left(J_{e}\right)$ in Eq. (12).

$\mathrm{T}$ a b u l'k a 3 . Hodnoty konštánt $\left(J_{e}\right)$ v rov. (12).

\begin{tabular}{lcccccc}
\hline Weir Type & $\mathrm{A}$ & $\mathrm{B}$ & $\mathrm{a}_{1}$ & $\mathrm{a}_{2}$ & $\mathrm{a}_{3}$ & $\varepsilon[\%]$ \\
\hline $\begin{array}{l}\text { Sharp-crested } \\
\text { triangular }\end{array}$ & $0.848^{\cos \alpha}$ & 2.223 & 0.039 & -0.418 & 1.000 & 5.5 \\
$\begin{array}{l}\text { Sharp-crested } \\
\text { rectangular }\end{array}$ & 16.608 & 2.101 & 0.028 & 0.086 & -28.998 & 10.8 \\
$\begin{array}{l}\text { Sharp-crested } \\
\text { trapezoidal }\end{array}$ & $\ln \left(\mathrm{Re}_{j}^{0.115}\right)$ & 1.596 & 0.043 & 0.107 & -19.246 & 4.3 \\
$\begin{array}{l}\text { Broad-crested } \\
\text { triangular }\end{array}$ & $0.394^{\cos \alpha}$ & 3.383 & -0.004 & -0.307 & 3.049 & 6.7 \\
$\begin{array}{l}\text { Broad-crested } \\
\text { rectangular }\end{array}$ & $\left(\ln \left(\mathrm{Re}_{j} / F_{j}\right)\right)^{-22.097}$ & 18.427 & 0.585 & -1.148 & 23.904 & 11.6 \\
$\begin{array}{l}\text { Broad-crested } \\
\text { trapezoidal }\end{array}$ & 0.719 & 16.94 & -0.118 & -0.480 & 2.486 & 2.2 \\
$\begin{array}{l}\text { Triangular } \\
\text { labyrinth }\end{array}$ & $1.445^{\cos \alpha}$ & 1.789 & 0.018 & 0.133 & -8.208 & 2.3 \\
\hline
\end{tabular}

${ }^{1)}$ ostrohranný trojuholníkový priepad, ${ }^{2)}$ ostrohranný pravouhlý priepad, 3) ostrohranný lichobežníkový priepad, ${ }^{4)}$ trojuholníkový priepad so širokou hranou, ${ }^{55}$ pravouhlý priepad so širokou hranou, ${ }^{6}$ lichobežníkový priepad so širokou hranou, ${ }^{7)}$ trojuholníkový labyrintový priepad.

The calculated penetration depth $D_{p o}$ is compared with the observed penetration depth $D_{p c}$ to yield the average percent error $\varepsilon$ as

$\varepsilon=\frac{100}{N} \sum_{i=1}^{N}\left|\frac{D_{p o}-D_{p c}}{D_{p o}}\right|$,

in which $N$ is the number of data points. The average percent error $\varepsilon$ is a function of the constant in the penetration depth equation. Eq. (15) can be also written for $L_{b}, J_{e}$ and $b_{u}$. The average percent error values belong to Eqs. (11)-(14) are given in Tabs. (1-4). Moreover, the measured bubble penetration depths are compared with those predicted with Eq.
(11). Good agreement between the measured bubble penetration depth and the values computed from the predictive equations is obtained. The values of $L_{b}$ measured are also compared with those predicted with Eq. (12). Good agreement between the measured $L_{b}$ and the values computed from the predictive equations is obtained. The measured $J_{e}$ are compared with those predicted with Eq. (13). Good agreement between the measured $J_{e}$ and the values computed from the predictive equations is obtained. The values of $b_{u}$ measured are compared with those predicted with Eq. (14). Excellent agreement between the measured $b_{u}$ and the values computed from the predictive equations is obtained. Further 
T a b l e 4. Values of constants $\left(b_{u}\right)$ in Eq. (13).

$\mathrm{T}$ a b u l'k a 4 . Hodnoty konštánt $\left(J_{e}\right)$ v rov. (13).

\begin{tabular}{lcccccc}
\hline Weir Type & $\mathrm{A}$ & $\mathrm{B}$ & $\mathrm{a}_{1}$ & $\mathrm{a}_{2}$ & $\mathrm{a}_{3}$ & $\varepsilon[\%]$ \\
\hline $\begin{array}{l}\text { Sharp-crested } \\
\text { triangular }\end{array}$ & $0.995^{\cos \alpha}$ & 5.371 & -0.044 & 0.164 & -2.177 & 1.4 \\
$\begin{array}{l}\text { Sharp-crested } \\
\text { rectangular }^{2)}\end{array}$ & 1.42 & 3.961 & -0.03 & 0.12 & -4.600 & 1.3 \\
$\begin{array}{l}\text { Sharp-crested } \\
\text { trapezoidal }^{3)}\end{array}$ & 1.924 & 3.642 & -0.018 & 0.093 & -5.787 & 1.3 \\
$\begin{array}{l}\text { Broad-crested } \\
\text { triangular) }\end{array}$ & $1.054^{\cos \alpha}$ & 2.288 & -0.006 & -0.190 & 0.867 & 2.1 \\
$\begin{array}{l}\text { Broad-crested } \\
\text { rectangular }\end{array}$ & 0.667 & 4.004 & -0.051 & 0.146 & -2.652 & 1.2 \\
$\begin{array}{l}\text { Broad-crested } \\
\text { trapezoidal }\end{array}$ & 0.125 & 5.781 & 0.082 & -0.343 & 2.112 & 1.4 \\
$\begin{array}{l}\text { Triangular } \\
\text { labyrinth }\end{array}$ & $1.007^{\cos \alpha}$ & 0.930 & -0.042 & 1.388 & -1.035 & 2.3 \\
\hline
\end{tabular}

${ }^{1)}$ ostrohranný trojuholníkový priepad, ${ }^{2)}$ ostrohranný pravouhlý priepad, ${ }^{3)}$ ostrohranný lichobežníkový priepad, ${ }^{4)}$ trojuholníkový priepad so širokou hranou, ${ }^{55}$ pravouhlý priepad so širokou hranou, ${ }^{6}$ lichobežníkový priepad so širokou hranou, ${ }^{7)}$ trojuholníkový labyrintový priepad.

confidence in the correlations is seen in Figs. 10, 11,12 , and 13 .

The following equations can be written for the determination of the minimum width, length and depth of the downstream receiving pool.

$W_{d} \geq J_{e}$,

$L_{d} \geq b_{u}+L_{b}$,

$z_{d} \geq D_{p}$,

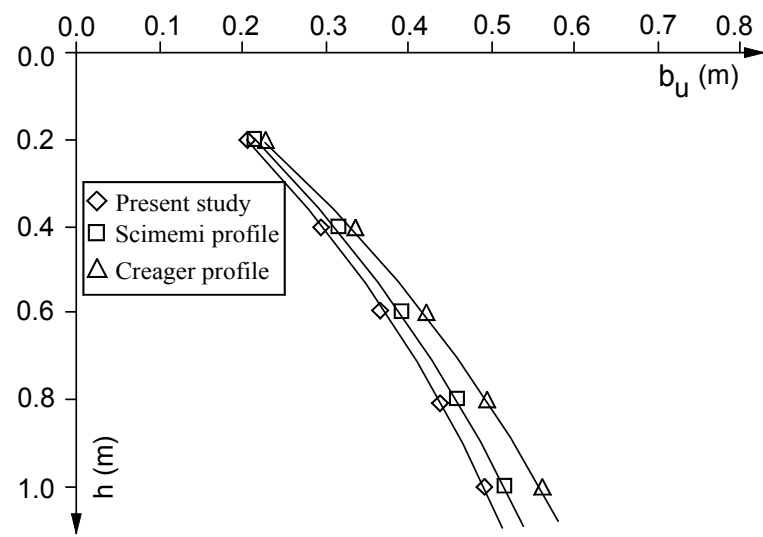

Fig. 9. Comparison of the $b_{u}$ values of rectangular broad crested weir with the equations of Scimemi and Creager.

Obr. 9. Porovnanie hodnôt $b_{u}$ pravouhlého priepadu so širokou korunou a výsledkami rovníc Scimemi a Creagera.

where $W_{d}$ - minimum width of downstream receiving pool $[\mathrm{m}], L_{d}-$ minimum length of downstream receiving pool $[\mathrm{m}]$, and $z_{d}-$ minimum tailwater depth $[\mathrm{m}]$.
In this study, tested discharges are smaller than that of some prototype applications. But, tested drop heights are similar to a lot of prototype scale. Scaling of bubble penetration depth data to prototype size is virtually impossible, largely due to the relative invariance of bubble size. Clearly, tests at higher discharges should be carried out to see if this trend extrapolates.

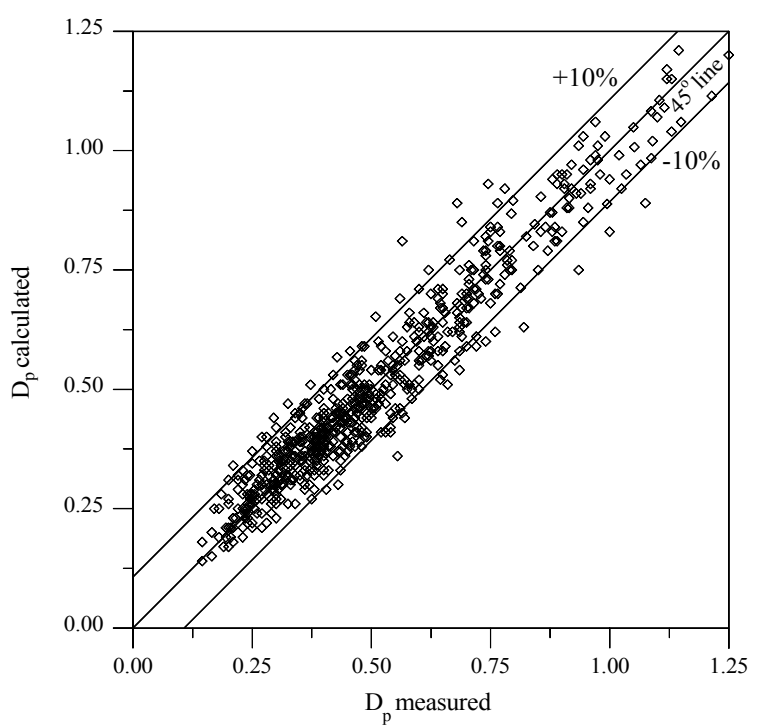

Fig. 10. Comparison of observed $D_{p}$ values with those calculated from Eq. (11).

Obr. 10. Porovnanie pozorovaných hodnôt $D_{p} \mathrm{~s}$ vypočítanými podl'a rov. (11). 


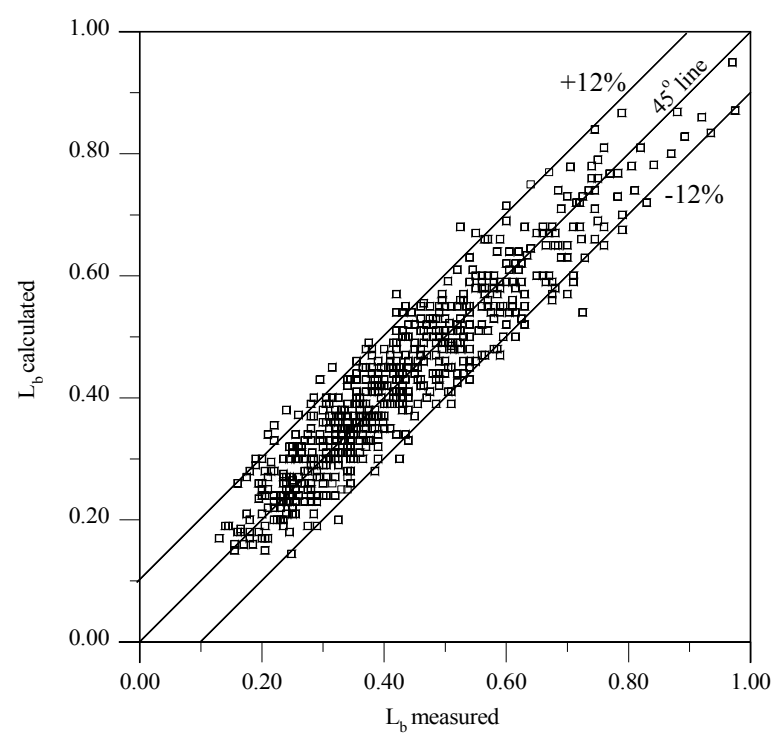

Fig. 11. Comparison of observed $L_{b}$ values with those calculated from Eq. (12).

Obr. 11. Porovnanie pozorovaných hodnôt $L_{b} \mathrm{~s}$ vypočítanými podl'a rov. (12).

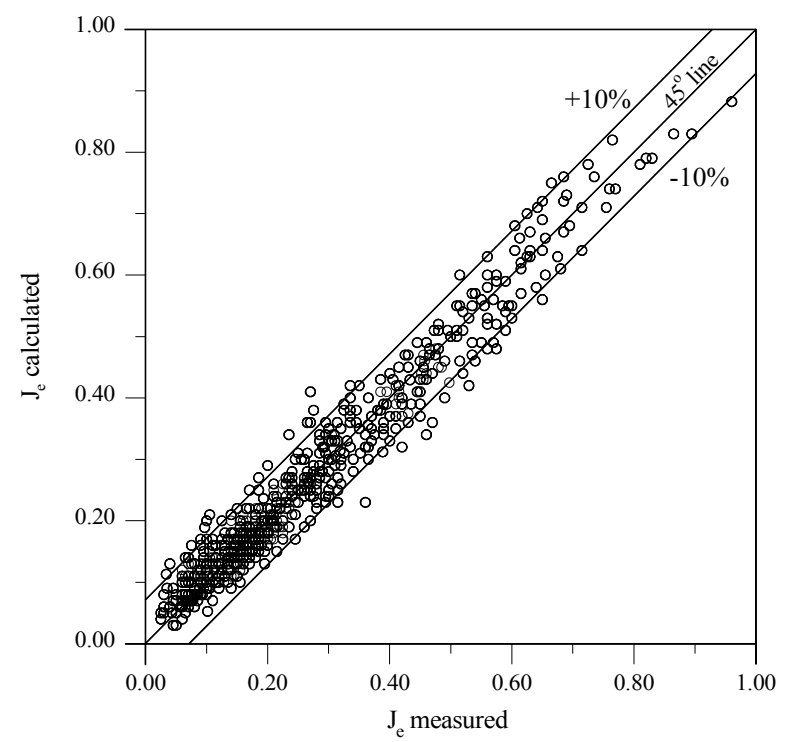

Fig. 12. Comparison of observed $J_{e}$ values with those calculated from Eq. (13).

Obr. 12. Porovnanie pozorovaných hodnôt $J_{e} \mathrm{~s}$ vypočítanými podl'a rov. (13).

\section{Conclusions}

The present experimental investigation estimates the free jet trajectory, the overfall jet expansion, and bubble penetration depth for different weir types and so dimensions of receiving pool. The correlations are developed for predicting the jet trajectory, overfall jet expansion, the maximum penetration depth, and the length of the bubble zone for different weir types. Downstream receiving pool using equations presented in this study have properly been designed as the optimum case. The concluding remarks obtained are as follows.

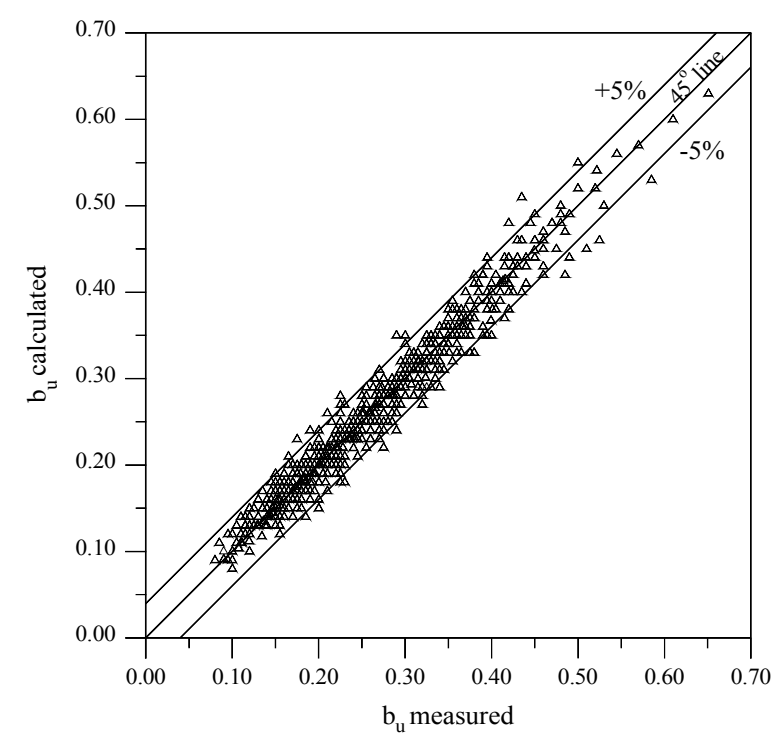

Fig. 13. Comparison of observed $b_{u}$ values with those calculated from Eq. (14).

Obr. 13. Porovnanie pozorovaných hodnôt $b_{u} \mathrm{~s}$ vypočítanými podl'a rov. (14).

1. The values of overfall jet expansion $J_{e}$, the bubble penetration depth $D_{p}$, jet trajectory, and the length of the bubble zone $L_{b}$ are different for each weir type and shape.

2. The overfall jet expansion $J_{e}$ increases with an increasing water discharge. The labyrinth weirs have the highest values of $J_{e}$. At the labyrinth weirs, $J_{e}$ increases as the included angle in the triangular labyrinth weirs decreases. The overfall jet expansion $J_{e}$ at the labyrinth weirs is significantly wider than the trapezoidal sharp-crested weir and the rectangular sharp-crested weirs. $J_{e}$ of the labyrinth weirs has shown an increasing tendency when drop height increased. The results indicate that the trapezoidal sharp-crested weir and the rectangular sharp-crested weirs have the lowest $J_{e}$. At the rectangular sharp-crested weirs, $J_{e}$ increases with an increasing crest width $B_{w}$. Furthermore, $J_{e}$ for the rectangular broad-crested weirs is wider than the rectangular sharp-crested weirs. For triangular sharp-crested weirs, $J_{e}$ increases as the angle of triangular weirs $\alpha$ decreases. The overfall jet expansion $J_{e}$ for the tri- 
angular broad-crested weirs is significantly smaller than the triangular sharp-crested weirs.

3. $D_{p}$ is closely related to the jet shape and expansion that is different for each weir type. The bubble penetration depth $D_{p}$ increases with increasing the water discharge. At the same time, the bubble penetration depth $D_{p}$ decreases with increasing drop height. The bubble penetration depth $D_{p}$ decreased with increasing $J_{e}$. The labyrinth weirs have the lowest values of $D_{p}$ among the weirs tested. The bubble penetration depth $D_{p}$ values for triangular labyrinth weir with included angle of $45^{\circ}$ are observed as the lowest one. The rectangular and trapezoidal sharp-crested weirs are observed to have the highest $D_{p}$ among all weirs tested. Especially, the trapezoidal sharpcrested weir has the highest $D_{p}$ values. At both triangular sharp-crested weirs and triangular broad-crested weirs, $D_{p}$ increases as the angle of $\alpha$ in triangular weirs increases.

4. The labyrinth weirs and triangular sharp-crested weirs with small angle are not appropriate due to enormous overfall jet expansion, if the downstream receiving pool width is very small.

\section{List of symbols}

$B_{w}$ - water surface width over the crest of the weir [m],

$b_{d}$ - distance of the downstream wall of the receiving pool to the center point of the jet where it impacts the water surface in the receiving pool $[\mathrm{m}]$,

$b_{\ell}$ - distance of the left side wall of the receiving pool to the center point of the jet where it impacts the water surface in the receiving pool $[\mathrm{m}]$,

$b_{L}$ - half-crest length in triangular labyrinth weir [m],

$b_{r}$ - distance of the right side wall of the receiving pool to the center point of the jet where it impacts the water surface in the receiving pool $[\mathrm{m}]$,

$b_{u}$ - distance of the upstream wall of the receiving pool to the center point of the jet where it impacts the water surface in the receiving pool [m],

$d$ - breadth in triangular labyrinth weir [m],

$D_{p}$ - bubble penetration depth [m],

$D_{p c}-$ calculated penetration depth [m],

$D_{p o}-$ observed penetration depth [m],

$\mathrm{E}_{u}$ - jet Euler number,

$\mathrm{F}_{i}$ - Froude number at the issuance,

$\mathrm{F}_{j}$ - jet Froude number,

$\mathrm{g}-$ acceleration due to gravity $\left[\mathrm{m} \mathrm{s}^{-2}\right]$,

$h$ - drop height [m],

$H_{w}$ - the vertical difference between the water surface in the upstream pool and the weir crest [m],

$J_{e}$ - overfall jet expansion [m],

$L$ - the experimental channel width [m],

$L_{b}$ - length of the bubble zone [m],

$L_{d}$ - minimum length of the downstream pool [m],

$L_{b r}$ - jet break-up length [m],

$L_{W}$ - length in triangular broad-crested weir [m],

$P_{\text {on }}$ - ambient pressure on the outer nappe of the jet $\left[\mathrm{N} \mathrm{m}^{-2}\right]$,
$P_{u n}$ - ambient pressure on the lower nappe of the jet $\left[\mathrm{N} \mathrm{m}^{-2}\right]$,

$\mathrm{Re}_{j}$ - jet Reynolds number,

$s$ - difference between crest and top in all weirs [m],

$T_{u}$ - initial turbulence intensity,

$Q$ - water discharge $\left[\mathrm{m}^{3} \mathrm{~s}^{-3}\right]$,

$Q_{A}$ - air entrainment rate $\left[\mathrm{m}^{3} \mathrm{~s}^{-3}\right]$,

$q_{j}$ - discharge through the per unit water surface width at the crest of the weir $\left[\mathrm{m}^{2} \mathrm{~s}^{-1}\right]$,

$v_{o}-$ average flow velocity in the upstream pool $\left[\mathrm{m} \mathrm{s}^{-1}\right]$,

$\mathrm{W}$ - jet Weber number,

$w$ - width in triangular labyrinth weir [m],

$W_{d}$ - minimum width of the downstream receiving pool [m],

$z$ - tailwater depth [m],

$z_{d}-$ minimum depth of the downstream pool [m],

$\alpha-$ angle in triangular sharp and broad-crested weir $\left[{ }^{\circ}\right]$,

$\varepsilon$ - average percent error,

$\theta \quad$ included angle in triangular labyrinth weir $\left[{ }^{\circ}\right]$;

$\mu-$ viscosity of the fluid (water) $\left[\mathrm{kg} \mathrm{s}^{-1} \mathrm{~m}^{-1}\right]$,

$\rho-$ density of fluid (water) $\left[\mathrm{kg} \mathrm{m}^{-3}\right]$,

$\rho_{\mathrm{a}}$ - density of gas (air) $\left[\mathrm{kg} \mathrm{m}^{-3}\right]$,

$\sigma-$ surface tension of the fluid (water) $\left[\mathrm{N} \mathrm{m}^{-1}\right]$.

\section{REFERENCES}

ALBRECHT D., 1968: Belüftung des ruhrwassers am wehr spillenburg. Die Wasserwirtschaft, 11.

APTED R.W., NOVAK P., 1973: Some studies of oxygen uptake at weirs. Proc. of the XV Congress, IAHR, Paper B23.

AVERY S.T., NOVAK P., 1978: Oxygen transfer at hydraulic structures. J. Hydraulic Div., ASCE, 104, 11, 1521-1540.

BAYLAR A., EMIROGLU M.E., 2002: The effect of sharpcrested weir shape on air entrainment. Canadian J. of Civil Engng., 29, 3, 375-383.

CASTILLO-E. L.G., 2007: Pressures characterization of undeveloped and developed jets in shallow and deep pool. $32^{\text {nd }}$ Congress of IAHR, the International Association of Hydraulic Engineering \& Research Venice, Italy, 1-6 July.

CHANSON H., 2004: The Hydraulics of Open Channel Flow: An Introduction. Butterworth-Heinemann, Oxford, UK, 495p.

CLANET C., LASHERAS J.C., 1997: Depth of penetration bubbles entrained by a plunging water jet. Phys. Fluids, 9, 7, 1864 $-1866$.

CREAGER W.P., JUSTIN J.D., HINDS J., 1945: Engineering for Dams, John Wiley \& Sons, New York, USA, 3 Volumes.

DAVIS A.C., JACOB R.P., ELLETT B.G.S., 1999: Estimating trajectory of free overfall nappe. J. of Hydraulic Engineering, $125,1,79-82$.

DEY S., 2002: Free overall in open channels: state-of-the-art review. Flow Measurement and Instrumentation, 13, 247-264.

EMIROGLU M.E., BAYLAR A., 2003: The effect of broadcrested weir shape on air entrainment. J. Hydraul. Res., 41, 6, 649-655.

EMIROGLU M.E., BAYLAR A., 2005: The Influence of included angle and sill slope on air entrainment of triangular planform labyrinth weirs. J. Hydraul. Engng., ASCE, 131, 3, 184-189.

GRINDROD J., 1962: British Research on Aeration at Weir. Water and Sewage Works, October.

HENDERSON F.M., 1966: Open Channel Flow. Macmillan, New York, USA.

ITO A., YAMAGIWA K.T., YOSHIDA M., OHKOWA A., 2000: Maximum penetration depth of air bubbles entrained by vertical liquid jet. J. Chemical Engng. of Japan, 33, 6, 898-900. 
KELLS J.A., SMITH C.D., 1991: Reduction of cavitation on spillways by induced air entrainment. Canadian J. Civil Engng., 18, 3, 358-377.

KOBUS H., KOSCHITZKY H.P., 1991: Local surface aeration at hydraulic structures. Edited by Ian R. Wood, Air entrainment in free-surface flows, IAHR, Hydraulic Structures Design Manual, 4, 29-53.

KUMAGAI M., ISHIZAKI H., ENDOH K., 1993: Penetration depth of bubble swarm entrained by a plunging water jet. J. Chemical Engng. of Japan, 26, 2, 217-219.

NAKASONE H., 1975: Applicable scope of equation of aeration and the region for aeration. Transactions, JSIDRE, 59.

NAKASONE H., 1987: Study of aeration at weirs and cascades. J. Environmental Engng., ASCE, 113, 1, 64-81.

NAKASONE H., 1976: Study on the effect of pollutant materials for oxygen transfer of falling water. J. Wat. and Waste, 17, 6.

SCIMEMI E., 1930: Sulla Forma delle Vene Tracimanti. L' Energia Elettrica, Milan, Italy, 7, 4, 293-305.

SCIMEMI E., 1937: Il profilo delle dighe sfiranti. L' Energia Elettrica.

TSANG C.C., 1987: Hydraulic and Aeration Performance of Labyrinth Weirs. [PhD thesis.] University of London, London.

USBR, 2001: Water Measurement Manual. A Water Resources Technical Publication, http://www.usbr.gov/pmts/hydraulics_lab /pubs/wmm/.

WAHL T.L., FRIZELL K.H., COHEN E. A., 2008: Computing the trajectory of free jets. J. Hydraulic Engng., ASCE, 134, 2, 256-260 .

WORMLEATON P.R., SOUFIANI E., 1998: Aeration performance of triangular planform labyrinth weirs. J. of Environmental Engng., ASCE, 124, 8, 709-719.

WORMLEATON, P. R., TSANG, C. C. 2000: Aeration performance of rectangular planform labyrinth weirs. J. Environmental Engng., ASCE, 126, 5, 456-465.

Received 3 September 2009 Accepted 23. June 2010

\section{URČOVANIE PRÚDOVÝCH CHARAKTERISTÍK ROZDIELNYCH TYPOV PRIEPADOV A OPTIMÁLNY NÁVRH VÝVARU}

\section{EMIN EMIROGLU}

Práca obsahuje výsledky experimentálneho výskumu určovania vol’nej dráhy (trajektórie) prúdu, expanzie prúdu pri prepade a híbku prieniku vzduchových bublín pre rozdielne typy priepadov. Boli navrhnuté korelačné závislosti pre výpočet trajektórie prúdu, jeho expanzie počas prepadu, maximálna híbka prieniku a dížka oblasti obsahujúcej vzduchové bubliny pre rozdielne typy priepadov. Rovnice, uvedené v tejto práci umožňujú optimálny návrh vývaru. Získané poznatky môžu byt' sformulované takto:

1. Hodnoty rozšírenia prúdu nad priepadom $J_{e}$, híbka prieniku bublín $D_{p}$, trajektória prúdu a dížka oblasti obsahujúcej bubliny $L_{b}$ sú pre rôzne typy priepadov rozdielne.

2. Rozšírenie prúdu nad priepadom $J_{e}$ sa zväčšuje so zvyšujúcim sa prietokom vody. Labyrintové priepady majú navyššiu hodnotu $J_{e}$. Pre labyrintové priepady $J_{e}$ sa zvyšuje so znižovaním sa uhla trojuholníkového labyrintového priepadu. Expanzia prúdu vody nad priepadom $J_{e} \mathrm{v}$ labyrintových priepadoch je širšia ako $\mathrm{v}$ lichobežníkových ostrohranných priepadoch a $\mathrm{v}$ pravouhlých ostrohranných priepadoch. $J_{e}$ labyrintových priepadov sa zvyšuje so zvyšujúcou sa výškou priepadu. Výsledky naznačujú, že lichobežníkový ostrohranný priepad a pravouhlý ostrohranný priepad majú najnižšie $J_{e}$. Pri pravouhlom ostrohrannom pravouhlom priepade $J_{e}$ sa zvyšuje so zvyšujúcou sa šírkou hrany $B_{w}$. Navyše, $J_{e}$ pre pravouhlý priepad so širokou priepadovou hranou je širšia, ako pre pravouhlý, ostrohranný priepad. Pre trojuholníkový, ostrohranný priepad $J_{e}$ sa zvyšuje so znižujúcim sa uhlom priepadu $\alpha$. Celkové rozšírenie prúdu $J_{e}$ pre trojuholníkový priepad so širokou hranou je výrazne menšie, ako pre ftrojuholníkový ostrohranný priepad.

3. $D_{p}$ je funkciou tvaru prúdu a jeho expanzie a je rozdielny pre rôzne typy priepadu. Híbka prieniku vzduchových bublín $D_{p}$ sa zvyšuje so zvyšujúcim sa prietokom. Súčasne sa hĺbka prieniku bublín vzduchu $D_{p}$ znižuje so zvyšujúcou sa výškou priepadu. Híbka prieniku bublín vzduchu $D_{p}$ sa znižuje so zvyšujúcim sa $J_{e}$. Najnižšiu hodnotu $D_{p}$ medzi testovanými priepadmi majú priepady labyrintové. Híbka prieniku bublín vzduchu $D_{p}$ pre trojuholníkový priepad s uhlom $45^{\circ}$ bola najnižšia. Híbka prieniku bublín vzduchu $D_{p}$ medzi testovanými priepadmi bola najvyššia pre pravouhlé a trojuholníkové ostrohranné priepady. Lichobežníkové ostrohranné priepady mali najvyššie hodnoty $D_{p}$. Pre oba trojuholníkové ostrohranné priepady a pre trojuholníkový priepad so širokou hranou sa $D_{p}$ zvyšovalo so zvyšujúcim sa uhlom $\alpha$ trojuholníkového priepadu.

4. Labyrintové a trojuholníkové ostrohranné priepady s malým uhlom nie je vhodné používat' tam, kde je malý vývar, pretože majú vel'kú expanziu prúdu.

\section{Zoznam symbolov}

$B_{w}$ - šŕrka hladiny vody nad hranou priepadu [m],

$b_{d}$ - vzdialenost' medzi dolnou stenou vývaru $\mathrm{k}$ bodu $\mathrm{v}$ strede prúdu dopadajúceho na hladinu vývaru [m],

$b_{\ell}$ - vzdialenost' lavej bočnej steny vývaru $\mathrm{k}$ bodu $\mathrm{v}$ strede prúdu dopadajúceho na hladinu vývaru [m],

$b_{L}$ - polovica dížky priepadovej hrany trojuholníkového labyrintového priepadu [m],

$b_{r}$ - vzdialenost' pravostrannej steny vývaru od bodu v strede prúdu dopadajúceho na hladinu vývaru [m],

$b_{u}$ - vzdialenost' protiprúdnej steny vývaru od bodu v strede prúdu dopadajúceho na hladinu vývaru [m],

d - šŕrka trojuholníkového labyrintového priepadu [m],

$D_{p}$ - híbka prieniku bublín [m],

$D_{p c}-$ vypočítaná híbka prieniku [m],

$D_{p o}-$ pozorovaná híbka prieniku [m],

$\mathrm{E}_{u}$ - Eulerovo č́slo prúdu,

$\mathrm{F}_{i}$ - Froudovo číslo vo výtoku,

$\mathrm{F}_{j}$ - Froudovo číslo prúdu,

g - gravitačné zrýchlenie $\left[\mathrm{m} \mathrm{s}^{-2}\right]$,

$h$ - výška priepadu [m], 
$H_{w}$ - vertikálny rozdiel medzi hladinou vody v hornej a dolnej zdrži priepadu $[\mathrm{m}]$,

$J_{e}$ - rozšírenie prepadového prúdu [m],

$L$ - šírka experimentálneho kanála [m],

$L_{b}$ - dížka prevzdušnenej oblasti (s bublinkami) [m],

$L_{d}$ - minimálna dížka vývaru [m],

$L_{b r}$ - dížka prepadového prúdu [m],

$L_{W}$ - dížka trojuholníkového priepadu so širokou hranou [m],

$P_{\text {on }}$ - tlak vzduchu na vonkajšej strane prepadového prúdu $\left[\mathrm{N} \mathrm{m}^{-2}\right]$,

$P_{u n}$ - tlak vzduchu na vnútornej (dolnej) strane prepadového prúdu $\left[\mathrm{N} \mathrm{m}^{-2}\right]$,

$\mathrm{Re}_{j}-$ Reynoldsovo číslo prúdu,

$s$ - rozdiel medzi priepadovou hranou a vrcholom všetkých priepadov [m],

$T_{u}$ - počiatočná intenzita turbulencie,

$Q$ - prietok vody $\left[\mathrm{m}^{3} \mathrm{~s}^{-3}\right]$,

$Q_{A} \quad$-rýchlost' unášania vzduchu $\left[\mathrm{m}^{3} \mathrm{~s}^{-3}\right]$, $q_{j}$ - prietok na jednotkovú dížku povrchu vody $\mathrm{v}$ korune priepadu $\left[\mathrm{m}^{2} \mathrm{~s}^{-1}\right]$,

$v_{o}$ - priemerná rýchlost' prúdenia $\mathrm{v}$ hornej zdrži $\left[\mathrm{m} \mathrm{s}^{-1}\right]$,

$W$ - Weberovo číslo prúdu,

$w$ - šírka trojuholníkového labyrintového priepadu [m],

$W_{d}$ - minimálna šírka vývaru [m],

$z$ - híbka vody v odtokovom kanáli [m],

$z_{d}$ - minimálna híbka vývaru [m],

$\alpha-$ uhol trojuholníkového ostrohranného priepadu a priepadu so širokou priepadovou hranou $\left[^{\circ}\right]$,

$\varepsilon \quad$ - priemerná chyba v percentách,

$\theta-$ uhol $\mathrm{v}$ trojuholníkovom labyrintovom priepade $\left[^{\circ}\right]$,

$\mu \quad$ viskozita tekutiny (vody) $\left[\mathrm{kg} \mathrm{s}^{-1} \mathrm{~m}^{-1}\right]$,

$\rho$ - hustota tekutiny (vody) $\left[\mathrm{kg} \mathrm{m}^{-3}\right]$,

$\rho_{\mathrm{a}}$ - hustota plynu (vzduchu) $\left[\mathrm{kg} \mathrm{m}^{-3}\right]$,

$\sigma-$ povrchové napätie tekutiny (vody) $\left[\mathrm{N} \mathrm{m}^{-1}\right]$. 